\title{
Effectiveness of Three Solvents and Two Associations of Solvents on Gutta-Percha and Resilon
}

\author{
Norberto Batista de FARIA-JÚNIOR \\ Livia Etchebehere de LOIOLA \\ Juliane Maria GUERREIRO-TANOMARU \\ Fábio Luis Camargo Villela BERBERT \\ Mário TANOMARU-FILHO
}

Department of Restorative Dentistry, Araraquara Dental School, UNESP - Univ. Estadual Paulista, Araraquara, SP, Brazil

\begin{abstract}
This study evaluated the effectiveness of 3 solvents (Citrol orange oil, Eucalyptol and Tetrachloroethylene) and 2 associations of solvents (Citrol orange oil+Tetrachloroethylene and Eucalyptol+Tetrachloroethylene) on 3 types of gutta-percha (conventional, thermoplastic and EndoREZ) and Resilon. Ten discs (10 mm diameter x $1 \mathrm{~mm}$ thick) from each material were prepared using standard metallic molds. Each specimen was weighed to determinate its initial mass. The specimens were immersed in the solvents for 10 min, followed by immersion in distilled water for $20 \mathrm{~min}$, and were then reweighed to obtain the final mass. The mean weight loss determined the solvent capacity. Data were analyzed by ANOVA and Tukey's test at 5\% significance level. Tetrachloroethylene was the most effective on conventional gutta-percha $(\mathrm{p}<0.05)$. Tetrachloroethylene was also the most effective on thermoplastic gutta-percha, but it was not significantly different ( $p>0.05$ ) from Eucalyptol+Tetrachloroethylene, Citrol+Tetrachloroethylene, and Citrol. All solvents and associations presented little effectiveness on Resilon. The association Eucalyptol+Tetrachloroethylene was the most effective on EndoREZ, but it did not differ significantly $(\mathrm{p}>0.05)$ from Citrol+Tetrachloroethylene and Tetrachloroethylene. All evaluated substances presented solvent action. Tetrachloroethylene improved the effectiveness of both Citrol and Eucalyptol.
\end{abstract}

Key Words: Gutta-percha, retreatment, solvent, Resilon.

\section{INTRODUCTION}

In endodontic treatment, solvents may be used to soften master cones to improve the apical adaptation to the root canal, and to facilitate the removal of guttapercha and sealers from the root canal system (1). The removal of root filling materials is often necessary during endodontic retreatment (2).

Retreatment procedures in endodontic practice require complete removal of the original root filling mass (3). The inability to remove all debris may result in the persistence of bacterial infection, which may result in endodontic failure. Root filling material removal might be done with or without the use of solvents. Nevertheless, the use of solvents has been reported to shorten the working time during retreatment, and to reduce the amount of debris on the dentin walls (4).

Several commercially available root canal sealers present distinct physicochemical characteristics (5), which may influence and determine the clinical efficacy of the solvents. In the same way, different brands of gutta-percha present some differences on their chemical compositions. Resilon (Pentron Clinical Technologies, Wallingford, CT, USA) has been introduced as an alternative to gutta-percha. It is a thermoplastic synthetic polymer-based root canal filling material. Hence, an ideal solvent should be able to dissolve a large variety of filling materials, as the clinician is unable to determine which one has been used in each single case.

Chloroform has been demonstrated to be one of the most effective solvent for root filling materials (6-8). However, due to its potential carcinogenicity, several materials have been studied as alternative (9). Among them, orange oil stands out for having low cytotoxicity (10) and good ability for dissolving root canal filling materials $(8,11)$. Another solvent frequently used clinically is Eucalyptol, which has been shown to be a suitable alternative to chloroform

Correspondence: Prof. Dr. Mário Tanomaru Filho, Rua Humaitá, 1680, Caixa Postal 331, Centro, 14801-903 Araraquara, SP, Brasil. Tel: +55-163301-6390. Fax: +55-16-3301-6392. e-mail: tanomaru@uol.com.br 
$(2,12)$. Tetrachloroethylene is the main compound of the Endosolv-E (Septodont, Paris, France), which has been used to dissolve gutta-percha and zinc oxide-eugenol sealers. However, little is known about its efficacy compared to other solvents.

Several studies have investigated the dissolving efficacy of organic solvents on root canal filling materials $(3,13)$. Nevertheless, there is no information about the association of solvents in order to improve their action. For this reason, it was hypothesized that the association of tetrachloroethylene with orange oil and eucalyptol would increase solvent ability of both these products. This study evaluated the effectiveness of 3 solvents (Orange oil, Eucalyptol and Tetrachloroethylene) and 2 associations (Orange oil+Tetrachloroethylene and Eucalyptol+Tetrachloroethylene) on 3 types of guttapercha (conventional, thermoplastic and EndoREZ) and Resilon.

\section{MATERIAL AND METHODS}

Three different types of gutta-percha, namely conventional gutta-percha (Endopoints, Paraíba do Sul, RJ, Brazil), thermoplastic gutta-percha (Endopoints), and EndoREZ gutta-percha (Ultradent Products Inc., South Jordan, UT, USA), and Resilon (Pentron Clinical Technologies) were used.

Ten discs (10 mm diameter x $1 \mathrm{~mm}$ thickness) from each material were fabricated for each solvent. The materials were immersed in water for $1 \mathrm{~min}$ in a water bath apparatus used to soften impression materials (Plastificador de Godiva Righetto e Cia., Campinas, SP, Brazil) at $70^{\circ} \mathrm{C}$, monitored by a digital thermometer. Following that, the heated materials were placed in standard metallic ring molds with the previously described dimensions, and pressed between 2 glass slabs under constant controlled pressure of $0.5 \mathrm{~N}$ for $1 \mathrm{~min}$. Next, the specimens were maintained at $37^{\circ} \mathrm{C}$ for $24 \mathrm{~h}$.

Each disc, along with its metallic ring, was weighed at 24-h intervals until stabilization for determination of the initial mass in grams. After weighing on a precision scale (model BL 210S; Sartorius, Gottingen, Germany) accurate to 0.0001 , the specimens were immersed in one of the solvents at $24 \pm 1^{\circ} \mathrm{C}$ for 10 $\mathrm{min}$, followed by immersion in distilled water for $20 \mathrm{~min}$ to neutralize the solvent action. After that, the specimens were removed from the water, stored at $37^{\circ} \mathrm{C}$ for $48 \mathrm{~h}$, and then reweighed at $24-\mathrm{h}$ intervals, until stabilization of the mass in order to determine the final mass.
The evaluated solvents were: Citrol orange oil (Biodinâmica, Ibiporã, PR, Brazil), Eucalyptol (Biodinâmica), Tetrachloroethylene (Percloroetileno PA; Synth Ltda., Diadema, SP, Brazil). Two associations were also tested: Citrol+Tetrachloroethylene (1:1), and Eucalyptol+Tetrachloroethylene (1:1).

The difference between the initial and final mass was calculated to determine the solvent action. Data were subjected to ANOVA and Tukey's test at 5\% significance level.

\section{RESULTS}

Figure 1 illustrates the solvent action of the solvents and associations on the materials. The mean mass loss of the different types of gutta-percha and Resilon is presented.

\section{DISCUSSION}

Nonsurgical retreatment of previously filled root canals demands that both the gutta-percha and the sealer be totally removed from the root canal walls. The root filling material can be removed by using manual or rotary files, ultrasonic instruments, heat pluggers, or laser, alone or in combination. These techniques can be done with or without the use of solvent solutions.

In the present study, the dissolving effect of 3 solvents and 2 associations on 3 types of gutta-percha and Resilon was evaluated. There is no international standards or tests to analyze the solubility of root canal filling materials in solvents. The ISO 6876:2001 standard (14) describes the procedure to determine the solubility of set sealer in water. According to the instructions, ring molds should have an internal diameter of $20 \mathrm{~mm}$ and a height of $1.5 \mathrm{~mm}$. Similar methods have been previously described $(3,6,7,11-13)$ using different ring molds sizes $(5 \times 2 ; 4 \times 2 ; 8 \times 2 ; 6.4 \times 1.6 \mathrm{~mm})$. This method provides a simple, reproducible, and cost-effective means of solubility evaluation (6). It must be kept in mind that this test allows only the comparison among different materials. Nevertheless, several clinically relevant parameters, such as contact area, contact time between root canal filling and solvent, temperature, solvent dilution by biological fluids or irrigants, interaction between irrigant and organic solvent, and volatility of solvents were not considered in the present study (7).

Although there are some reports in the literature regarding the solubility of endodontic sealers immersed 
in organic solvents $(3,6,7,11)$, little is known about their effects on Resilon and different types of gutta-percha. The findings of the present study demonstrated that all solvents and associations had little effectiveness on Resilon. The worst result was obtained by Orange oil. This result is in agreement with those of Tanomaru-Filho et al. (13). A previous study (4) assessed the efficacy of retreatment of root canals filled with the Epiphany/ Resilon System with and without solvent (chloroform). Retreatment time in the non-solvated subgroup was significantly longer than in the solvent one. Time required to complete retreatment in the experimental group (Epiphany/Resilon) was significantly longer than in the control group (AH Plus/gutta-percha). Additionally, residue percentage was greater in Epiphany/Resilon. In another study, Oliveira et al. (15) showed that the group obturated with the Resilon system presented quicker removal than the group obturated with gutta-percha. In the present study, the association Citrol+Tetrachloroethylene obtained the best result and might therefore be considered for using in root canals filled with Resilon. Despite the limited solvent action of all solvents and associations on Resilon, in a clinical situation these substances might still be helpful to allow

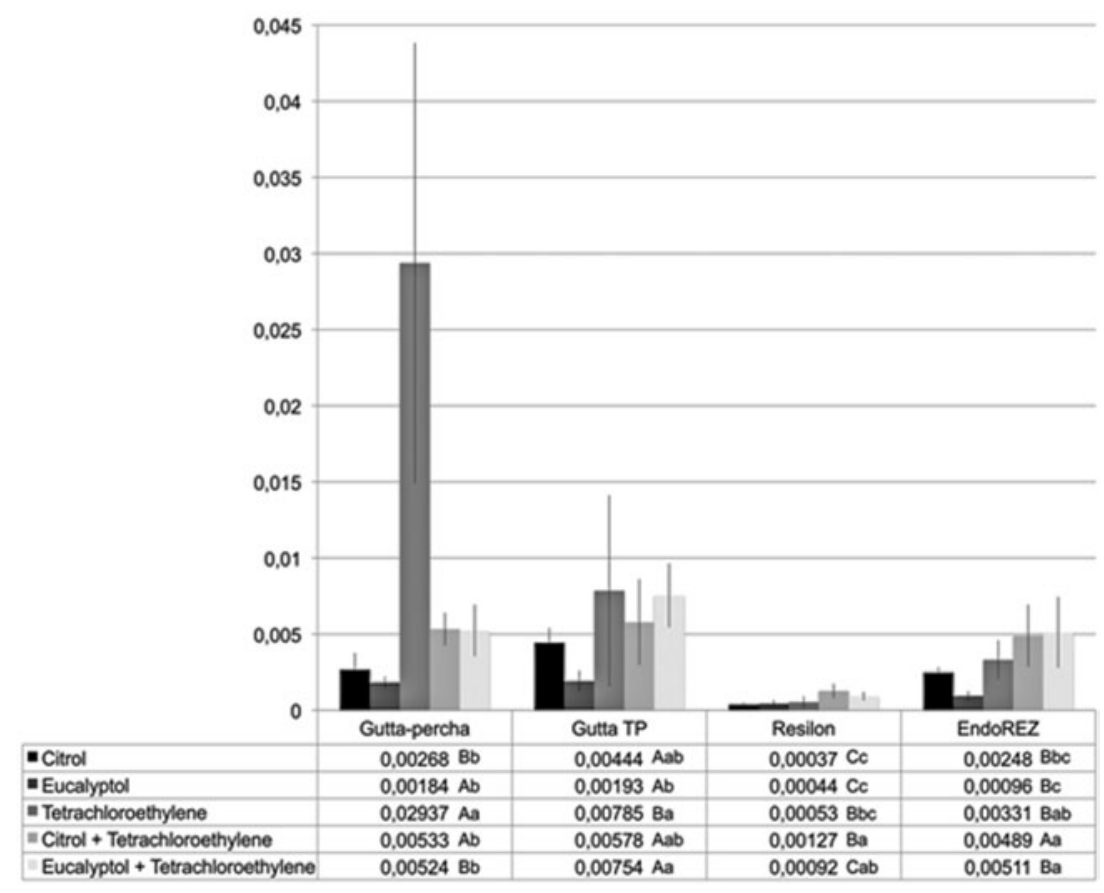

Figure 1. Mean mass loss ( $\mathrm{g}$ ) of the root canal filling materials after immersion in the different solvents. Different uppercase letters indicate statistically significant difference among the endodontic filling materials $(p<0.05)$. Different lowercase letters indicate statistically significant difference among the solvents $(\mathrm{p}<0.05)$. the penetration of the file into the material.

Methacrylate resin coated gutta-percha cones (EndoREZ Points) have recently been introduced in attempt to establish a bond between sealer/gutta-percha. Hammad et al. (16) measured the remaining filling volume of the EndoREZ system (EndoREZ sealer and EndoREZ points) from root-filled teeth by using 2 removal techniques, manual K-files or rotary ProTaper retreatment files. In both techniques, about $0.2 \mathrm{~mL}$ of eucalyptol oil was injected into the coronal part of the root canal to soften the filling material. The EndoREZ System was better removed by using hand files, but there was not significantly difference from rotary files. In another study, Somma et al. (17) found that both ProTaper Universal retreatment files and Mtwo R required less time to remove the EndoREZ System than using a manual technique. Chloroform solvent was only used in the manual group. There are no reports of the solubility of EndoREZ points in solvents. Our findings suggest that the associations Citrol+Tetrachloroethylene and Eucalyptol+Tetrachloroethylene presented better action in softening the EndoREZ cones. Thus, one of these 2 associations might be a useful tool during root canal retreatments filled with the EndoREZ System.

In this study, Citrol and Eucalyptol presented similar dissolving efficacy on conventional gutta-percha. This is in agreement with others studies $(2,12,13)$. In contrast, Pecora et al. (8) showed that the orange oil presented a better softening action on guttapercha cones than the Eucalyptol. Additionally, Oyama et al. (18) assessed the effectiveness of 5 different solvents on softening gutta-percha in simulated root canals and showed better action with Orange oil than Eucalyptol. According to obtained results Tetrachloroethylene was more effective than the others substances on conventional gutta-percha. Tetrachloroethylene was also the most effective on thermoplastic gutta-percha, but it was not significantly different from Eucalyptol+Tetrachloroethylene, Citrol+Tetrachloroethylene, and 
Citrol. Kaufman et al. (19) assessed histochemically the effect of chloroform, xylene, and Endosolv-E (Tetrachloroethylene) on the calcium and phosphorus levels of cut human dentin surface, and found that changes following treatment with the gutta-percha solvents were minimal.

The biocompatibility of solvents should be of great concern regarding the possibility of overfill of such substances that might not be tolerated by the periapical tissues, and hence might inhibit or retard the repair process (10). In addition, cytotoxicity is considered a secondary mechanism in non-genotoxic carcinogenesis (20). The choice of an ideal solvent for endodontic retreatment requires the establishment of a balance between the level of toxicity and aggression to the tissues, and the chemical capacity of dissolution (12). Further studies are needed to investigate the biocompatibility of the 2 associations used in the present study.

Within the limitations of this in vitro study, it is possible to conclude that: all evaluated substances presented solvent action; Tetrachloroethylene was the most effective on conventional gutta-percha; all solvents and associations showed little effectiveness on Resilon; and Tetrachloroethylene improved the effectiveness of both Citrol and Eucalyptol.

\section{RESUMO}

Este estudo avaliou a efetividade de 3 solventes (Citrol, Eucaliptol e Tetracloroetileno) e 2 associações (Citrol+Tetracloroetileno e Eucaliptol+Tetracloroetileno) sobre 3 tipos de guta-percha (convencional, termoplástica e EndoREZ) e Resilon. Dez discos (10 $\mathrm{mm} \times 1 \mathrm{~mm})$ de cada material foram preparados utilizando moldes metálicos. Cada espécime foi pesado para determinar a massa inicial. Os mesmos foram imersos nas soluções testadas por $10 \mathrm{~min}$ e em água destilada por $20 \mathrm{~min}$. Os espécimes foram novamente pesados, agora para determinar a massa final. A perda média de peso determinou a capacidade solvente. Os dados foram analisados pelos testes ANOVA e Tukey. O tetracloroetileno foi o mais efetivo sobre a guta-percha convencional $(p<0,05)$. Ele também foi o mais efetivo sobre a guta-percha termoplástica, mas sem diferença significativa para o Eucaliptol+Tetracloroetileno, Citrol+Tetracloroetileno e o Citrol $(p>0,05)$. Todos os solventes e associações apresentaram pequena ação sobre o Resilon. A associação Eucaliptol+Tetracloroetileno obteve o melhor resultado sobre o EndoREZ, mas sem diferença significativa para o Citrol+Tetracloroetileno e o Tetracloroetileno $(\mathrm{p}>0,05)$. Todas as soluções apresentam ação solvente. O Tetracloroetileno melhorou a efetividade do Citrol e do Eucaliptol.

\section{REFERENCES}

1. Erdemir A, Eldeniz AU, Belli S, Pashley DH. Effect of solvents on bonding to root canal dentin. J Endod 2004;30:589-592.
2. Hansen MG. Relative efficiency of solvents used in endodontics. J Endod 1998;24:38-40.

3. Bodrumlu E, Er O, Kayaoglu G. Solubility of root canal sealers with different organic solvents. Oral Surg Oral Med Oral Pathol Oral Radiol Endod 2008;106:e67-69.

4. Hassanloo A, Watson P, Finer Y, Friedman S. Retreatment efficacy of the Epiphany soft resin obturation system. Int Endod J 2007; 40:633-643.

5. Versiani MA, Carvalho-Junior JR, Padilha MI, Lacey S, Pascon EA, Sousa-Neto MD. A comparative study of physicochemical properties of AH Plus and Epiphany root canal sealants. Int Endod J 2006;39:464-471.

6. Whitworth JM, Boursin EM. Dissolution of root canal sealer cements in volatile solvents. Int Endod J 2000;33:19-24.

7. Schafer E, Zandbiglari T. A comparison of the effectiveness of chloroform and eucalyptus oil in dissolving root canal sealers. Oral Surg Oral Med Oral Pathol Oral Radiol Endod 2002;93:611-616.

8. Pecora JD, Spano JC, Barbin EL. In vitro study on the softening of gutta-percha cones in endodontic retreatment. Braz Dent $\mathrm{J}$ 1993;4:43-47.

9. Vajrabhaya LO, Suwannawong SK, Kamolroongwarakul R, Pewklieng L. Cytotoxicity evaluation of gutta-percha solvents: Chloroform and GP-Solvent (limonene). Oral Surg Oral Med Oral Pathol Oral Radiol Endod 2004;98:756-759.

10. Scelza MFZ, Lima Oliveira LR, Carvalho FB, Corte-Real Faria $\mathrm{S}$. In vitro evaluation of macrophage viability after incubation in orange oil, eucalyptol, and chloroform. Oral Surg Oral Med Oral Pathol Oral Radiol Endod 2006;102:e24-27.

11. Martos J, Gastal MT, Sommer L, Lund RG, Del Pino FA, Osinaga PW. Dissolving efficacy of organic solvents on root canal sealers Clin Oral Investig 2006; 10:50-54.

12. Magalhaes BS, Johann JE, Lund RG, Martos J, Del Pino FA. Dissolving efficacy of some organic solvents on gutta-percha. Braz Oral Res 2007;21:303-307.

13. Tanomaru-Filho M, Orlando TA, Bortoluzzi EA, Silva GF, Tanomaru JM. Solvent capacity of different substances on guttapercha and Resilon. Braz Dent J 2010;21:46-49.

14. International Organization for Standardization (2001). Dental root canal sealing materials. ISO 6876:2001.

15. Oliveira DP, Barbizam JV, Trope M, Teixeira FB. Comparison between gutta-percha and resilon removal using two different techniques in endodontic retreatment. J Endod 2006;32:362-364.

16. Hammad M, Qualtrough A, Silikas N. Three-dimensional evaluation of effectiveness of hand and rotary instrumentation for retreatment of canals filled with different materials. J Endod 2008;34:1370-1373.

17. Somma F, Cammarota G, Plotino G, Grande NM, Pameijer CH. The effectiveness of manual and mechanical instrumentation for the retreatment of three different root canal filling materials. J Endod 2008;34:466-469.

18. Oyama KO, Siqueira EL, Santos M. In vitro study of effect of solvent on root canal retreatment. Braz Dent J 2002;13:208-211.

19. Kaufman D, Mor C, Stabholz A, Rotstein I. Effect of gutta-percha solvents on calcium and phosphorus levels of cut human dentin. J Endod 1997;23:614-615.

20. Ribeiro DA, Marques ME, Salvador DM. In vitro cytotoxic and non-genotoxic effects of gutta-percha solvents on mouse lymphoma cells by single cell gel (comet) assay. Braz Dent J 2006; 17:228-232. 